\title{
ISLAM AND ITS IMPACT ON WOMEN'S STATUS AND ROLE IN EGYPT
}

\author{
Wahyuddin Halim \\ Fakulty of Ushuluddin and Filsafat \\ UIN Alauddin Makassar \\ Email:whalim@temple.edu
}

\section{Abstract:}

Gender relations in Islam has been the subject of serious debates among scholars in Egypt for many decades. One of the central questions was whether the status and role of women in Egypt were and are primarily influenced by Islam, or they should also be attributed to other social, economic, cultural and political factors. This study will look at the status and role of women in modern Egypt. It is commonly known that traditions based largely on religion (including Islam) and superstition are strong elements in the Egyptian culture. However, this study will show that the inequity in gender relations in modern Egypt should be more attributed to socioeconomic factors than to those religious or theological beliefs. On the other hand, one cannot overlook the formative influence of Islam on the roles of women and men in the country both in the past and in the present. The study suggests that attempts to reinterpret, reassess and re-actualize Islamic doctrines and practices pertaining to the equal status and roles of women in the context of Egyptian culture should also be considered in order to alter the women and men's perception on gender relations. 
Keywords: Gender-Status - Role - Egypt

\section{Introduction}

The study of women in Islam and a Muslim society such as Egypt is complex, reflecting the diverse and varied realities of Muslim women and Muslim societies throughout the ages. Alongside ideals embodied in the Quran and traditions (badith) of the Prophet Muhammad, one must look at the actual condition of Muslim women in diverse time periods and sociohistorical contexts. The status of women in Islam was profoundly affected not only by the fact that Islamic belief interacted with and was informed by diverse cultures, but also, and of equal importance, that the primary interpreters of Islamic law and tradition were men (religious scholars or ulama) from those countries. ${ }^{1}$

The subject of gender relations in Islam is highly charged not only at the popular level, but also among scholars. If someone blames Islam for the accumulated ills of Muslim women, others see it as a beacon of light and reform. Still others insist that the status and role of women in Muslim societies should be attributed more to socioeconomic forces than to religious or theological belief. The explanations often seem as numerous as the subject. However, one cannot overlook the formative influence of Islam on the roles of women and men in Muslim societies both in the past and in the present.

It is under the light of this assumption that this section will discuss the status and role of women in modern Egypt. That is, whether the status and role of women in Egypt were and are primarily influenced by Islam, the religion adhered by the majority of Egyptian people, or they should also be

\footnotetext{
${ }^{1}$ Yvonne Yazbeck Haddad and John L. Esposito, Islam, Gender and Social Change. Oxford: Oxford University Press, 1998), p. xii.
} 
attributed to other social, economic, cultural and political factors. It is important here to first of all briefly discuss Islamic historical and textual account on women status and role before engaging ourselves on a specific issue on Egyptian women.

\section{Egyptian Women and its Islamic Background}

The introduction of Islam following the Arab conquest of Egypt in 640 A.D. undoubtedly comprises the single most important determinant not only in constructing the character of Egyptian culture and religion ${ }^{2}$ but also in bringing about a profound effect on the status of women. According to Lane, ${ }^{3}$ Islam becomes the main foundation of the Egyptian manner and customs. It is understandable, for instance, if Egyptian women share many of the characteristics and face many of the same problems as women in other Arab-Islamic countries. $^{4}$

However, it should not be easily thought, as many writers did, that the reality of women in this country, as well as in other Middle East Muslim countries, to be simply revert to Islam for both description and cause of women's position. ${ }^{5}$ This is simply because the history of women in Egypt itself, especially in the nineteenth century, refutes this static version of the past due to the fact that women, through their own actions and endeavors, were affected by and

${ }^{2}$ P.J.Vatikiotis, The Modern History of Egypt (New York: Frederick A. Praeger, 1969).

${ }^{3}$ Lane, Edward William. 1890. An Account of the Manners and Customs of the Egyptian. London: Ward, Lock and Co., 1890), p. 53.

${ }^{4}$ Soha Abdel Kader, Egyptian Women in a Changing Societym 1899-1987. Boulder \& London: Lynne Rienner Publisher, 1987), p. 7.

${ }^{5}$ Judith E. Tucker, Women in nineteenth-century Egypt (Cambridge: Cambridge University Press, 1985), p. 3. 
helped to shape the sweeping change of each period of their history. ${ }^{6}$ Moreover, the Turk influence on women when Egypt came under the rule of the Turks in 1517 should also be taken into account. This is because the Turks relegated Egyptian women suffered a loss in their rights and freedom.

Because of the above-mentioned and any other factors, the role of women in pre-Islamic Egypt seems to be considerably different from that in other parts of the Middle East. The role of women, at least initially, even influenced the interpretation of Islamic precepts pertaining to the place of women. Moreover the Islamic social order, far from being static in Egypt, has experienced important changes within the past fourteen centuries. ${ }^{8}$ Women in ancient Egyptian civilization enjoyed high prestige, respect and status in all aspects of life. In this context, Ancient Egyptian culture that gave high respect to women is therefore unique among some other ancient cultures, such as the Greek, which relegated women to a subordinate status. ${ }^{10}$ With the beginning of the patriarchal class system, however, as will be discussed later in the following

\section{${ }^{6} \mathrm{Ibid}$.}

${ }^{7}$ Audrey Chapman Smock and Nadia Haggag Youssef, "Egypt: From Seclusion to Limited Participation," in Janet Zollinger Giele and Audrey Chapman Smock, eds. Women Roles and Status in Eight Countries (New York: John Wiley and Sons, 1977), p. 40.

${ }^{8}$ Smock and Youssef, Ibid.,p. 35.

${ }^{9}$ Nawal El Saadawi, "Women's Resistance in the Arab World and in Egypt", in Haleh Afshar. Women in the Middle East: Perceptions, Realities and Struggles for Liberation (Hampshire: Macmillan.El Saadawi, 1993), p. 139.

${ }^{10}$ Smock and Youssef, “Egypt,” p. 35. 
section, women started to lose their position in relation to men. ${ }^{11}$

It is likely due to the above mentioned facts that the influence of Islam on the status of women has been a matter of debate frequently, although invariably with reference to the ninth century Arabian society rather than to Egypt. ${ }^{12}$ Islam, as an integral religion, formulates a total pattern of living rather than focusing primarily on theology. ${ }^{13}$ Therefore, Muhammad, unlike Jesus, was concerned with the role of women. As Levy tells us: "in so fundamental a matter as the position held by women and children in his community, Muhammad was able to introduce profound change." ${ }^{14}$

The verses in the Quran and the hadiths (pronouncement of the Prophet) that deal with women do not, however, systematically define women's roles and status. Their ambiguity has provoked considerable controversy regarding the Prophet's views and intentions. Some modernist Muslim thinkers think that although Islam has given women rights, but why and what kinds of rights and by what rationale are not clear. ${ }^{15}$ In addition, the four major legal schools within Islamic tradition have differed in their interpretation of the sources of revelation, including on the issue of women status and rights. The fact is that legal scholars within the Hanafite schools, the dominant tradition in Egypt, have also changed some of their

\footnotetext{
${ }^{11}$ El Saadawi, ibid., p. 139.

${ }^{12}$ Abdel Kader, Egyptian Women, p. 4-5.

${ }^{13}$ See H.A.R. Gibb, ed., Wither Islam? (London: George
} and Allen, 1932)

${ }^{14}$ Ruben Levy, The Social Structure of Islam. Cambridge: Cambridge University Press., 1965), p. 91.

${ }^{15}$ Fazlur Rahman, Islam and Modernity Challenge (Chicago: Chicago University Press, 1982), p. 153. 
views with the passing of time partly to adopt the new situation. ${ }^{16}$

Historically, the Arabian society that predated Mohammad's revelations apparently accorded women considerable freedom and did not maintain the seclusion of women. Pre-Islamic poetry, for instance, portrayed women as able to freely interact with men and to actively involve in communal affairs, including in spiritual domain. ${ }^{17}$ There seem to have been few restrictions on marriage and divorce, and women, at least under some circumstances, were able to choose their husbands. ${ }^{18}$ However, women did not enjoy secure legal rights. Besides, in spite of the fact that women's status was not low, the society practices female infanticide. ${ }^{19}$

Mohammad, it is thought by some, sought to transform the tribal basis of Arabian society by substituting a more family-oriented pattern based on a partnership between the sexes, albeit one in which the women was the junior partner. To accomplish his goal Mohammad attempted to invest women with secure legal rights, although not equal to those of men. ${ }^{20} \mathrm{He}$ also accepted them into the community of believers and offered them the same rewards of heaven enjoyed by men to give their wife or wives a decent and respectable life. Mohammad also categorically banned the continued practice of female infanticide; he accorded to women the right to own property and to receive a share of inheritance. Some scholars consider him to be somewhat reluctant in sanctioning the continuation of polygamy, but recommended that men limit

\footnotetext{
${ }^{16}$ Fazlur Rahman, Islam (1968), pp. 85-89, 92-94

${ }^{17}$ Margareth Smith, Rabi'a the Mystic and Her Fellow-Saints in Islam (Cambridge: Cambridge University Press, 1928).

${ }^{18}$ Shafiq, 1956

${ }^{19}$ Levy, op. cit., p. 91.

${ }^{20}$ See Gibb in Smock and Youssef, "Egypt, “" p. 35.
} 
themselves to one wife and did not allow them to marry more than four women at the same time. However, according to Muhammad Abduh, a leading modern Egyptian Muslim scholar, polygamy had been permitted in the Prophet's time as a concession to the prevailing social condition. The fact is, Abduh thinks, the true intent of the Quranic verses dealing with this issue (IV:3 and IV:129), its ideal, was monogamy. ${ }^{21}$

One major factor contributing to the conservative evolution of Islamic society with regard to the interpretation of the proper roles for women was the pressure of the ideal of tribal honor. ${ }^{22}$ As Arab society became more family oriented through the impact of Islam, male honor came to depend on the virtue of the family's female members. At the same time men's image of women emphasized female sexuality and postulated that women were weak and irresponsible. Thus it was believed that free contact between men and women inexorably led to a sexual relationship. Seclusion and veiling of women served the purpose of protecting the family from possible humiliation by the transgressions of its women. Although the veil became a symbol of respectability, the very logic of seclusion reflected negatively on the character and value of women. Ultimately women were kept apart from men to shield men from the temptations that women, who were inherently untrustworthy, inevitably offered. The confinement of women to home obviously limited the roles they could assume and their ability to enforce their rights. ${ }^{23}$

The traditional roles and status of women in Egypt in pre-Islamic times differed considerably from those in Arabia, and therefore the impact of Islam on the status of women was not the same. As has been mentioned above, women in Egypt

${ }^{21}$ John L. Esposito, Women in Muslim Family Law (New York: Syracuse University Press, 1982), p. 51.

${ }^{22}$ See Gibb in Smock and Youssef, "Egypt," p. 37.

${ }^{23}$ Smock and Youssef, "Egypt," p. 37. 
already held many of the rights that Islam introduced to other areas of the Middle East. Moreover from many centuries Egyptian society resisted the application of a more conservative interpretation of the prescriptions in Islam from women. ${ }^{24}$ Many classical Egyptian Arabic sources describe women as shopping, even buying clothes from their husbands. Ibn alHadj, a fourteenth century Egyptian jurist, inveighed against many of the practices of women which he perceived as contrary to Islamic laws, such as the use of henna, the tattooing of the body, the wearing of many jewels, and the removal of unwanted hair from the face; he would not have been aware of the manner in which women dressed if they had been veiled and secluded. ${ }^{25}$

Thus, two major question be asked here: If the ancient Egyptian history has witnessed the high status of women and if the Islamic teaching and law have given the equal rights to them in the modern time, why do then Egyptian women's status and role remain not fully significant relatively compared to men? What other factors have affected and are affecting this process of change within Egyptian community regarding women? It is hoped that by exemplifying the following two aspects of Egyptian women's life these questions could be resolved.

\section{Egyptian Women in Major Economic Activities}

Public statistics indicate that Egyptian women have an exceedingly low level of participation in economic activities outside home. The first census of women participating in the wage-earning labor force in Egypt was conducted in 1914. From this census, only 20.000 or 5 percent of the total number of employees are women at the time. ${ }^{26}$ However, the total

\footnotetext{
${ }^{24}$ Esposito, Women, p. 51-52.

${ }^{25}$ Smock and Youssef, "Egypt," p. 40.

${ }^{26}$ El Saadawi, “Women's Resistance," p. 140.
} 
female activity rate, that is, the proportion of females in the labor force out of the total female population reported in 1968 for all occupation sectors was 8.1 percent. $^{27}$ This figure represents an increase of 5.8 percent within 21 years.

It is also important to note although rural women make a substantial contribution to farm activities, and consequently, to the economy of their families and their country, little of the agricultural activities of rural women are included in official economic statistics of the country. ${ }^{28}$ It is true that in many ways women are the backbone of the rural economy. But if Egyptian women's labor force participation rates in the modern sector are compared with countries at comparable stages of economic development outside of the Islamic world, it can be seen that the involvement of the Egyptian women in the work outside of the home is relatively low. Moreover Egypt's economic development has not been paralleled by an increase in the number of women who are employed in nonagricultural activities. Nor can the relative absence of women from the paid labor force be explained by an unfavorable structure of demand in the labor market. A detailed breakdown of the industrial and occupational structure of the work force in Egypt reveals that men hold jobs usually filled by women in other societies.

According to Smock and Youssef, the low level of economic participation of Egyptian women outside the home is characteristic of Islamic societies and reflects cultural definitions of the sexual division of labor. ${ }^{29}$ The women's

\section{"Egypt."}

${ }^{27}$ Fahmy and Ramzi, 1974, in Smock and Youssef,

${ }^{28}$ Jean D. Dickerscheid. "Profiles of Rural Egyptian Women Rules, Status and Needs," in Das, Man Singh and Vijay Kumar Gupta, eds. Social Status of Women in Developing Countries (New Delhi: MD Publications PVT LTD.Dickerscheid, 1995), p. 43; and Smock and Youssef, "Egypt."

${ }^{29}$ Smock and Youssef, "Egypt." 
sphere is seen as the household, and the external world of work and public affairs is reserved for men. Rural women can participate in agricultural cultivation only because this is considered to be part of their household duties. When quantitative data are compared, say Smock and Youssef, ${ }^{30}$ Muslim societies consistently show the lowest female activity rates in nonagricultural employment. ${ }^{31}$

The prohibition against women's working may be well represented by the abhorrence expressed by both men and women toward women's economic activities outside of the home. Muslim women are restricted by the suspicion, mistrust, and fear that paid employment outside the home represents for the family and community at large. This challenge affects the Muslim male equality in his role of father, brother, or husband, which explains why kinsmen feel compelled to assume economic responsibility for all their women whether these are single, divorced, or widowed. ${ }^{32}$ In an interview with the Grand Sheikh of Al-Azhar University, the ultimate authority on Islamic interpretation in Egypt, he was quoted as saying:

"Islam does say that the financial support for a wife should be the responsibility of the husband. But in unfortunate circumstances and times of poor economy such as now [around 1993-wh], it is permissible for women to help support their families by working. All that Islam asks is that

\footnotetext{
${ }^{30}$ Smock and Youssef, "Egypt."

${ }^{31}$ Wedad Zenie-Ziegler, In Search of Shadows; Conversations with Egyptian Women. London and New Jersey: Zed Books, 1988).

${ }^{32}$ Smock and Youssef, "Egypt."
} 
women who work behave correctly with men, help themselves above suspicion, and not try to seduce men. ${ }^{\text {"33 }}$

In fact, Sadat's “open-door" policy, which permitted easy access for foreign investment in Egypt throughout the 1970s, tended to favor upper-middle-class women, especially in the area of high paying jobs. ${ }^{34}$ However, because of the socio-cultural context, until 1977, in general, few Egyptian women have been induced to seek employment unless required to do so by terrible economic need or inspired to seek a career through higher education. In understanding the desire of women themselves, it is important to remember that until now the acknowledgement of kinship support has eliminated from the Egyptian women's existence the need to work for economic survival. Moreover, while economic demands have encouraged women in the upper middle class to seek work outside the home, work is not viewed as an absolute necessity. It is a means of improving the family standard of living and in particular of producing extra income that can be used to buy more expensive clothes and other luxury items. ${ }^{35}$

At the same time the social and psychological penalties paid by the average Egyptian women who chooses to work is more important than the social and economic advantages that women obtain from the work situation, especially since female attainments in extra familial activities are not sources

${ }^{33}$ Jan Goodwin, Price of Honor: Muslim Women Left the Veil of Silence on the Islamic World (New York: Penguin Group, 1994), p. 347.

${ }^{34}$ Safia K. Mohsen, "New Images, Old Reflections: Working Middle-Class Woman in Wgypt," in Elizabeth Warnock Fernea, ed. Women and the Family in the Middle East: New Voices of Change. Austin: University of Texas Press, 1985), p. 56.

${ }^{35}$ Mohsen, Ibid., p. 58. 
of social recognition. In addition, notwithstanding the apparent changes in the aspiration of Egyptian women, the most important goal for women of all classes remains very traditional. ${ }^{36}$ According to Mohsen, the vast majority of Egyptian women still view success in terms of a husband and a happy family life. ${ }^{37}$ The implicit or explicit atmosphere of mistrust and suspicion, which surrounds all working women, is further compounded for the single girls into the fear of spinsterhood, and for divorcee, into the likelihood of reduced chances for remarriage. For the married woman the penalties involved could lead to the disruption of her marital life, and possibly to its dissolution. Under a legal system in which polygamy is permitted and in which the rights to divorce and custody of children are the sole prerogative of the male, such threats and penalties assume a certain sense of reality. ${ }^{38}$

Among the small group of women who opt for employment outside the home several striking trends can be seen. However, within the domestic sphere, women's public role has required some adjustment. ${ }^{39}$ Well-educated middle and upper-class Egyptian women have fewer inhibitions against working than women who come from social classes that have a greater need for a supplementary income. Related to this, women in the labor force are clustered in occupation that require an education. Sex segregation in the society also has its consequence in the types of jobs that women accept; at all levels of occupational structure the suitability of jobs for women depends on the degree of contact with men they necessitate.

${ }^{36}$ Nayra Atiya, Khul-Khaal: Five Egyptian Women Tell Their Stories (Syracuse: Syracuse University Press, 1982), p. xiii.

${ }^{37}$ Mohsen. Ibid. p. 67.

${ }^{38}$ Smock and Youssef, "Egypt."

${ }^{39}$ Mohsen, Ibid., p. 59. 
Young women are socialized to believe that they have only one option in life: to be a wife and mother. ${ }^{40}$ As educational opportunities improve for women, so do their chances for employment. Statistics showed that Younger women and women from urban backgrounds have a greater tendency to seek employment than do older women and women residing in the rural areas. ${ }^{41}$ Strides have also been in law reforms including improving women's rights in marriage, divorce, inheritance, their rights to vote, labor, laws, their rights to run for public office, and their rights to custody of children. ${ }^{42}$ Few researchers have integrated rural Egyptian women's feelings, perceptions and attitudes about themselves and about their relationships with men since the implementation of these changes in education, employment, and law. However, women's roles change as they grow older. ${ }^{43}$

The new economic demands have also pushed more lower-middle-class women into the work force. Lacking the resources needed to enter lucrative business fields, the majority of lower-middle-class women seeking work have found employment in public sector jobs, particularly in government offices. $^{44}$

Most employed women are concentrated in the relatively few occupations that are considered respectable for

${ }^{40}$ Ramzi, in Smock and Youssef, "Egypt."

${ }^{41}$ Smock dan Youssef, "Egypt."

${ }^{42}$ Esposito, Ibid.; Andrea B. Rugh, Family in Contemporary Egypt (New York: Syracuse University Press, 1954); and Smock dan Youssef, "Egypt."

${ }^{43}$ Saad Gadalla and Hanna Rizk, "Population Policy and Family Planning Communication Strategies in the Arab States Region," in Population Communication Technical Documentation. Vol. II, no. 6 (Paris: UNESCO, 1985).

${ }^{44}$ Mohsen, Ibid., p. 60. 
women. Women in many countries complain of the rigidity in their occupational structure. However the obviously closed occupational opportunity structure that restricts women from employment involving contact with men makes the situation in Egypt, as in other Muslim countries, unique. The imperative of sex-segregated employment for women has accorded to men a virtual monopoly over many types of jobs commonly filled elsewhere by women. To quote Abdel Kader's words on gender system in Egypt:

"The men were the breadwinners; it was their responsibility and duty to work in the public domain, to work outside the home, to provide for their women-folk and children. Work for the women of this class and age, particularly work for money, was considered degrading and shameful for the women themselves and for the men who were responsible for their upkeep. A woman of this class sought to earn her own living only if there were no man in her family, be it husband, father, son, or brother, able and willing to support her.... The women's main functions were to be good wives and, more importantly, to procreate..."

The greater labor force participation by women in urban areas, 10.6 percent as compared to 4 percent for rural families in $1969{ }^{46}$ may reflect the urban environment's somewhat more liberal attitude toward women working, more frequent opportunities for wage employment, and higher concentration of educated women. The disparity in activity rates for women may, however, also result from an understanding of the economic figure implies, rural women usually assist with farm work. Rural housewives frequently undertake fieldwork, food processing, seeding, animal husbandry, cutting, weeding, and carrying of fertilizer. Men

\footnotetext{
${ }^{45}$ Abdel Kader, Ibid., p. 25.

${ }^{46}$ Fergany as quoted in Smock and Youssef, "Egypt."
} 
cannot undertake some of these tasks without inviting public disapproval for engaging in what is regarded as a woman's job. ${ }^{47}$

Statistics reveal that younger Egyptian women are far more likely to work than older ones. Female participation in the labor force reaches its maximum in the 10 through 14 age group and decreases proportionately with advancing age to a minimum in the 65 years and older group. Women employment reaches its peak in the 35 through 39 age groups and then declines gradually. ${ }^{48}$ Two different lines of interpretation can be used to explain these trends. Because the seclusion of women, according to traditional mores, need not take place until puberty, preadolescence girls are allowed to engage in work. After women marries and has children it is increasingly less acceptable for her to undertake economic activities outside the home. ${ }^{49}$ Alternatively, it can be reasoned that younger women have a greater proclivity to disregard some traditional restrictions either because they are more likely to be educated or because standards are slowly changing. Nevertheless not too much should be made of this trend. ${ }^{50}$

Other factors also contribute to women's low rates of participation. Many employers believe that women make poor workers. Problems with absenteeism are far more pronounced for women, particularly married women, than for men. Women tend to report late for work. Their lack of geographic mobility precludes the accepting of transfers even if such reassignments entail promotions. ${ }^{51}$ Working women everywhere must cope

${ }^{47}$ See Margareth Smith, Rabi'a the Mystic and Her FellowSaints in Islam (Cambridge: Cambridge University Press, 1970). "Egypt."

${ }^{48}$ Fahmy and Ramzi as quoted in Smock and Youssef,

${ }^{49}$ Rugh, Ibid., p. $72-77$.

${ }^{50}$ Smock and Youssef, "Egypt.”; Rugh, Ibid., p. 77-79.

${ }^{51}$ Ibrahim Barbara Lethem, "Family Strategies: A Perspective on Women's Entry to Labor Force in Egypt," in 
with the problem of reconciling familial responsibilities with the career obligations, but in Egyptian society the disapproval of women everywhere accepting employment outside the home exacerbates these difficulties. It should be noted, however, that women do not generally exhibit more problematic pattern of behavior or lower productivity than do their male coworkers. ${ }^{52}$

Provision of Egyptian labor code frequently makes the hiring of women more expensive. Egypt labor laws demand equality of pay while at the same time they require many special benefits for women. Many of the laws, some of which date back forty years, also forbid the employment of women in types of work considered to be physically harmful or strenuous. Most of the regulations currently in force reflect the standard established by the ILO conventions. ${ }^{53}$

As in many other countries, many of the provisions relating regulating the employment of women are honored in the breach. For example, many enterprises fail to provide nurseries facilities. According to 1970 statistics, there are only 978 nurseries catering to 46,998 children, some two-thirds of which are located in rural areas. ${ }^{54}$ Despite the laws mandating that women receive equal pay for equal work, women usually paid lower wages. The difference between the averages for women and men is more pronounced in agriculture than in

Das, Man Singh, ed.. Roles of Women in Muslim Countries (New Delhi: M.D. Publication PVT Ltd., 1991); Margot Badran, Feminist, Islam and Nation: Gender and the Making of Modern Egypt (New Jersey: Princeton University Press, .1995) and Badran (1972) in Smock and Youssef, "Egypt."

${ }^{52}$ Badran (1972) in Smock and Youssef, "Egypt"; Mohsen, op.cit., p. 62-62. "Egypt."

${ }^{53}$ Fahme and Taha (1972) in Smock and Youssef,

${ }^{54}$ Abdel Kader, Op.cit., p. 41; Ibrahim, loc. cit.. 
industry and commerce, and smaller in the service sector. ${ }^{55}$ Employers frequently contravene the 1959 law that forbids discrimination according to sex. Societal conventions defining the type of employment deemed appropriate for women discourage them from applying for many jobs, but women are also discriminate by the government and private organizations, which reserve positions for men. Women therefore remain excluded from some occupation because the labor laws are not actively enforced.

Over the past few years, among urban educated circles in Egypt sentiment has been voiced informally concerning changes in the institutional position of the Egyptian women in the social structure. This sentiment was profoundly motivated by several women's movements and figures who struggle for the enhancement of women status in social and political life. ${ }^{56}$ Unfortunately the extent and degree to which this is reflected in women's overt behavior cannot be verified empirically, since no census material is available for his country since $1960 .^{57}$

Economic pressures have undoubtedly induced changes in the attitudes of young Egyptian men. The implicit atmosphere of mistrust and suspicion that has traditionally surrounded the workingwoman in Islamic countries is lessening considerably in a country like Egypt, where young males may now find it more advantageous to marry girls who hold jobs. The economic advantages that double salary can provide to the young married couples desirous to improve their standard of living. Such economic motivations, if they are to continue over time, will soon translate themselves at the societal level into

\footnotetext{
${ }^{55}$ Badran (1972) p. 17 in Smock and Youssef, "Egypt."

${ }^{56}$ See Azza M. Karam, Women, Islamism and the State: Contemporary Feminism in Egypt (London: McMillan Press, Ltd., 1998); Fernea and Bezirgan, 1977; Abdel Kader, loc. cit.

${ }^{57}$ Smock and Youssef, "Egypt,” p. 62.
} 
viewing and rewarding more favorably the status of the employed female. ${ }^{58}$

Another current trend in the role of Egyptian women in development in their country is migration and international remittance. As studied by Adams, international remittances of both Egyptian men and women working in foreign countries have positive effect in alleviating poverty, particularly in rural Egypt. The employees of this type come from both those classified to be among the lower level class or middle-class economy of this country. ${ }^{59}$

\section{The Issue of Fertility and Family Planning}

According to the 1986 census, the total number of Egypt's population rose to 50.5 million. Ten years later, the 1996 census noted that the population soared to 61.4 million including 2.1 million Egyptian temporary immigrants with an increase of 11 million. ${ }^{60}$ The population growth rate dropped to $2.8 \%$ in 1986 compared to $2.1 \%$ in 1996 , indicating a fall by 7 per thousand in overpopulation over the last ten years. However, a decline in mortality in the last ten years with no concomitant change in the level of fertility has resulted in rapid increase in population. The current rate of population growth according to 1996 census, 2.1 percent, if unchecked, may result in doubling of the population within a 25 years period. Population growth is expected to rise 62,056 million in $1998 / 1999$, with an increase of 1,217 million at an annual growth rate nearly $2 \%$. The rate of annual population increase

${ }^{58}$ Ibrahim, loc. cit.; Smock and Youssef, "Egypt,” p. 62.

${ }^{59}$ Richard H. Adam Jr., "The Effects of International Remittances on Poverty, Inequality, and Development in Rural Egypt," (Research Report. International Rood Policy Research Institute, 1986.).

${ }^{60}$ SIS.GOV 
represents a significant rise over the figures computed from some previous censuses in this century, which varied from a low of 1.1 percent in 1972, to a high of $2.9 \%$ in $1992 .{ }^{61}$

As can be seen from 1996 census, such growth places a great strain on the country -from both the pace at which the population is growing and the total burden of its size. A considerable portion of Egypt's resources must be used to provide basic services for the growing population rather than being invested to accelerate economic development. Moreover Egypt as a whole is already densely populated and cannot sustain a doubling or tripling of its populace, particularly since most of its surface area is unsuitable for habitation or cultivation. $^{62}$

Official recognition of the population growth problem came in 1962. The National Charter issued in that year states that; "This increase [in population growth] constitutes the most dangerous obstacle that faces the Egyptian people in their drive towards raising the standard of production in their country in an effective and efficient way". ${ }^{63}$ The government established a national policy to reduce population growth in 1965, with the goal, set in 1969, to reduce the crude birth rate by one point per year for 10 years. The government provides free birth control service and subsidized contraceptives through both public and private medical facilities. As of 1970 the Supreme Council for Family Planning, the national body vested with responsibility for directing the program, reported that 619,000 people accepted family-planning services offered in the national program; 458,000 of these in the eligible couples - not a sufficiently high proportion to have a significant impact in

\footnotetext{
${ }^{61}$ Ibid.

${ }^{62} \mathrm{~EB}$; SIS.GOV.

63 "The Charter" (1962), p. 61 cited in Smock and Youssef, "Egypt."
} 
reducing the rate of population growth. ${ }^{64}$ However, this family planning which is nationally programmed is still a controversial issue in this country, as in many other Muslim countries. ${ }^{65}$ Not everyone believes, accepts, or follows government guidelines, this as a result of cultural, economic, strategic or religious factors.

Like many other countries, Egypt has culturally factors that greatly affect the willingness of couples to limit their fertility. One subject of some controversy has been the prenatal tendencies contained within Islam. Several writers have maintained that Islam's strong prenatal orientation stems less from direct injunction to procreate than from support of conditions that result in high fertility. ${ }^{66}$ The reputed famous statement of the Prophet, "Marry and reproduce so that I may be proud of you before God, ${ }^{, 67}$ is not borne out by any direct reference to it in the Quran. Children, especially male children, are considered among the richest blessing Allah can bestow, but they do not constitute the primary values. ${ }^{68}$ Surrender and obedience surpass by far the importance of wealth and children. High fertility pattern may, however, have been also stimulated by the fatalistic elements in Islamic theology, one of which is Jabarism, which are based on the strong belief in the active

\footnotetext{
${ }^{64}$ Supreme Council for Family Planning (1971), p. 15 as cited in Smock and Youssef, "Egypt."

${ }^{65}$ See Malladi Subbama, Islam and Women (New Delhi: Sterling Publisher Private Limited, 1998). P. 119-120.

${ }^{66}$ Sklani (1960), p. 831-836 and Kirk (1968), p. 231 in Smock and Youssef, "Egypt."

${ }^{67}$ Dickerscheid, op. cit., p. 39. cit., p. 41.

${ }^{68}$ Smock and Youssef, "Egypt", p. 64; Abdel Kader, op.
} 
providence of God. It is Allah who creates sexuality and determines procreation and barrenness. ${ }^{69}$

Jabarism (predeterminism) is a teaching which stresses the necessity for human beings to accept God's decision in all matters. This theology believes that human being do not have communicative-abilities at all before God. As a result, they cannot be responsible for their deeds, right or wrong. The implication of this teaching still can be observed in Egyptian's Muslim response to family planning. Followers of Jabarism "consider the use of contraception to control one's progeny to be in opposition to predestination, i.e., a mistrust in the ability of Allah to provide for children or simply a negation of basic reliance on Allah. They cite numerous verses from the Qur'an to support their opinion." ${ }^{, 70}$

On the contrary, the Quran contains no ambivalence with respect to the importance of marriage for the Muslim population at large. This importance is located in the following specific institutional and religious prescriptions: All Muslim males are enjoined to marry in order to "complete half their religion"; the early and universal remarriage of widowed and divorced women is highly encourage and sanctioned; purpose of marriage is explicitly stated to be not only procreation but the gratification of spiritual and physical needs. This means that sexual intercourse within marriage is given a positive valuation independent of reproduction itself. ${ }^{71}$

On the other hand, fertility control is not prohibited in Islam. Historically, the Quran has justified coitus interruptus to protect the male's property, to preserve the wife's health, and

\footnotetext{
${ }^{69}$ Smock and Youssef, "Egypt." P. 64-65; see also Stowasser, 1998, p. 34-35.

${ }^{70}$ A. R. Omran, Family Planning in the Legacy of Islam (London: Routledge.Omran, 1992), p. 89.

${ }^{71}$ Esposito, op. cit., p. 53-55; Smock and Youssef, "Egypt." P. 65.
} 
to relieve uneasiness over numerous children. Modern legal opinions support measures to prevent conception, and religious leaders in several Muslim countries have endorsed familyplanning programs by declaring them to be sanctioned by Islamic doctrine. Only abortion and permanent sterilization are still met with strong opposition from Islamic religious authorities. $^{72}$

As a matter of fact, most studies on Islam and family planning indicate that family planning is permitted by Islam. ${ }^{73}$ However, there is some disagreement about the condition under which family planning can be accepted and practiced. Several studies indicated a need for research to clarify the social and economic circumstances, necessitating family planning in accordance with the teachings of Islam about the welfare of the individual, and the prosperity and strength of society. ${ }^{74}$ In one of his noticeable books, Canon in Medicine (al-Qanun fi al-Tibb), Ibnu Sina, a major Islamic figure in science and philosophy, just to take an example of these studies, mentions his position on family planning (contraception) based on medical justification. His stands on the issue was as follows: contraception is acceptable when (1) the youth of the wife renders her unable to bear children, for physical reasons; (2) there is bladder weakness or fear of incontinence resulting from pressure of the head of fetus during labor; (3) a disease is present that could be exacerbated by pregnancy or labor, leading to the death of mother (Omran, 1992: 173).

Apparently, the ulama (traditional Muslim scholars) who forbid family planning as well as those who allow it both base their decision on the textual understanding of the Prophet tradition (hadith) and the Quran. However, in addition to this

\footnotetext{
${ }^{72}$ Rahman, Islam; and Subbama, loc. cit.

${ }^{73}$ Rahman, Islam and Modernity,; Haddad and Esposito, loc. cit.

${ }^{74}$ Gadalla, op. cit., p. 55.
} 
textual understanding, the contextual interpretation is also an important reason in permitting contraception. According to Musallam, the reasons for allowing family planning at the time were as follows: "(1) Marriage was treated as polygamous; (2) Legitimate sexual intercourse was not confined to marriage, but extended also to the institution of concubinage; (3) Marriage was not viewed as a permanent relationship; easy divorce could end it at any time; (4) Marital intercourse needed no justification by procreative purpose, and was also based on the right to sexual fulfillment; (5) Contraception was permitted and abortion tolerated." 75

According to Smock and Youssef, the lack of doctrinal injunction against most methods of birth control may prove to be a double-edge sword. "It is to be hoped," they say, "that very lack of prohibition will allow introduction and acceptance of desired contraceptive techniques." "76 Nevertheless, the absence of an organized clergy in Islam, in fact, has meant that every parochial leader can interpret his religious texts and faith, as far as he is able to understand it. Individual definitions of the situation and consequent variations in interpretation could conceivably impede the implementation of fertility control programs or family planning. Whereas according to Dickersheid, religion, together with superstition, on which traditions are based is the dominant factors in the Egyptian culture and may replace the law in creating concrete practices. ${ }^{77}$

${ }^{75}$ B.F. Musallam, Sex and Society in Islam: Birth Control Before the Nineteenth Century (Cambridge: Cambridge University Press, 1983), p. 11 as quoted in Andi Faisal Bakti, "Communication, Islam, and Development in Indonesia: An Analysis of the Different Perspectives of the South Sulawesi Muslim Population on Family Welfare and Planning," (Ph.D. dissertation Concordia University, Montreal, 1998), p. 158-159

${ }^{76}$ Smock and Youssef, "Egypt," p. 64-65.

${ }^{77}$ Dickersheid, op. cit., p. 38. 
In fact, the status of women in Egyptian society has profoundly influenced their reproductive behavior and eventually it seems to motivate prenatal tendencies. To quote Smock and Youssef:

Through socialization, limited access to educational facilities, and erosion of the incentive for working, women are systematically exposed of any options other than marital and motherhood-related roles. Prohibitions imposed informally by males act in combination with resistance to change by women and reinforce the system, despite initial breakthroughs in economic modernization. Women, fully aware of the importance of marital position and motherhood for commanding respect and status within their own kin group and the community at large, are not about to deemphasized their only bargaining position in the social structure. ${ }^{78}$

As already mentioned, being an investment within their families, children represent much more than a form of social insurance against the threat of divorce or polygamy for women who derive status from their motherhood role, even if they are divorced or rejected for a second wife. Children guarantee women status and respect that extend far beyond their position in the conjugal home; they raise her own family's valuation of her and that of the community at large. Hence women tend to continue childbearing activities throughout their reproductive years whether they are happily married or not. This becomes also a hindrance in the implementation of family planning.

Education, according to Smock and Youssef, seems to be the most important variable affecting the level of fertility among Egyptian women. ${ }^{79}$ There are several ways by which education works to reduce fecundity. First, by pursuing

\footnotetext{
${ }^{78}$ Smock and Youssef, "Egypt,” p. 65.

${ }^{79}$ Ibid.
} 
higher education, fertile women are able to delay marriage as well as to postpone the start of childbearing. Secondly, and more importantly, education seems to expand a woman's horizons and change her aspirations. Highly educated women, for example, show a far greater propensity to seek employment and become economically independent. Although the educated Egyptian woman is not ready to give up marriage for a career, her attempt to reconcile traditional roles with employment motivates her to have fewer children. Thirdly, education also makes women more concerned about the types of contraception available and enables them to be more efficient users. Due to this awareness, highly educated women are more successful in achieving the desired number of children than are women with less education. ${ }^{80}$ Consequently, Smock and Youssef suggested, improving women's access to education might be the most effective long-term means of reducing the rate of population growth. ${ }^{81}$

\section{Concluding Remarks}

Notwithstanding the importance of education both in reducing the rate of population growth, as it is suggested by Smock and Youssef, and in improving their access to labor markets, in my opinion, the need for reinterpreting, reassessing and re-actualizing the Islamic doctrines and practices pertaining to the status and role of women in society in the context of Egyptian culture should also be taken into consideration in order to alter the women and men's perception on women's work. ${ }^{82}$ Another major important factor that operates in

\footnotetext{
${ }^{80}$ Khalifa and Khalifa (1973), p. 222 in Ibid.

${ }^{81}$ Smock and Youssef, "Egypt."

${ }^{82}$ Ibid.
} 
Islam and its impact on women's status and role in Egypt

improving women's status and roles both in family and social life is reformulating and re-enforcing the family law based on the contextual interpretation of Islamic texts dealing with women. However, in order this law can be effectively implemented, it should be followed by effective ways of communication to socialize the law within all elements of society, one of which is religious approach. This is simply because, as already mentioned above, traditions based largely on religion and superstition are strong elements in the Egyptian culture and may supersede the law in determining actual practices. 


\section{BIBLIOGRAPHY}

Adam, Jr Richard H.., "The Effects of International Remittances on Poverty, Inequality, and Development in Rural Egypt," Research Report. International Rood Policy Research Institute, 1986.

Atiya, Nayra, Khul-Khaal: Five Egyptian Women Tell Their Stories Syracuse: Syracuse University Press, 1982.

Badran, Margot, Feminist, Islam and Nation: Gender and the Making of Modern Egypt.New Jersey: Princeton University Press, .1995 .

Billing, M Alvesson, \& YD, Understanding Gender and Organisations, SAGE, London, 1999.

Das, Man Singh and Vijay Kumar Gupta, eds. Social Status of Women in Developing Countries. New Delhi: MD Publications PVT LTD.Dickerscheid, 1995.

Esposito, John L. Women in Muslim Family Law. New York: Syracuse University Press, 1982.

Esposito, Yvonne Yazbeck Haddad and John L., Islam, Gender and Social Change. Oxford: Oxford University Press, 1998.

Fernea, Elizabeth Warnock, ed. Women and the Family in the Middle East: New Voices of Change. Austin: University of Texas Press, 1985.

Gibb, H.A.R., ed., Wither Islam?. London: George and Allen, 1932.

Goodwin, Jan, Price of Honor: Muslim Women Left the Veil of Silence on the Islamic World. New York: Penguin Group, 1994.

Haleh, Afshar. Women in the Middle East: Perceptions, Realities and Struggles for Liberation. Hampshire: Macmillan, 1993. 
Islam and its impact on women's status and role in Egypt

Kader, Soha Abdel, Egyptian Women in a Changing Societym 18991987. Boulder \& London: Lynne Rienner Publisher, 1987.

Karam, Azza M., Women, Islamism and the State: Contemporary Feminism in Egypt. London: McMillan Press, Ltd., 1998

Levy, Ruben, The Social Structure of Islam. Cambridge: Cambridge University Press., 1965.

Munro, A, Women, Work and Trade Unions: Employment and Work Relations in Context Series, Mansell, London, 1999.

Musallam, B.F., Sex and Society in Islam: Birth Control Before the Nineteenth Century. Cambridge: Cambridge University Press, 1983.

Norris, RD Barron \& GM, 'Sexual Divisions and the Dual Labour Market', in DL Barker \& S Allen [eds.], Dependence and Exploitation in Work and Marriage, Longman, London.

Omran, A. R., Family Planning in the Legacy of Islam. London: Routledge. Omran, 1992.

Perkins, V Beechey \& T, A Matter of Hours, University of Minnesota, Minneapolis, 1987.

Rahman, Fazlur, Islam and Modernity Challenge. Chicago: Chicago University Press, 1982.

Rizk, Saad Gadalla and Hanna, "Population Policy and Family Planning Communication Strategies in the Arab States Region," in Population Communication Technical Documentation. Vol. II, no. 6 Paris: UNESCO, 1985.

Rogers, B, The Domestication of Women, Tavistock Publication, London, 1980.

Rugh, Andrea B. Family in Contemporary Egypt. New York: Syracuse University Press, 1954. 
Singh, Das, Man, ed.. Roles of Women in Muslim Countries. New Delhi: M.D. Publication PVT Ltd., 1991.

Smith, Margareth Rabi'a the Mystic and Her Fellow-Saints in Islam. Cambridge: Cambridge University Press, 1928.

Smith, Margareth, Rabi'a the Mystic and Her Fellow-Saints in Islam. Cambridge: Cambridge University Press, 1970.

Subbama, Malladi, Islam and Women. New Delhi: Sterling Publisher Private Limited, 1998.

Tong, RP, Feminist Thought: A More Comprehensive Introduction, ALLEN and UNWIN, Sydney, 1998, p. 96.

Tucker, Judith E., Women in nineteenth-century Egypt. Cambridge: Cambridge University Press, 1985.

Vatikiotis, P.J., The Modern History of Egypt. New York: Frederick A. Praeger, 1969.

Walby, S Walby, Theorizing Patriarchy, Basil Blackwell, Oxford, 1990.

Walby, S, Gender Segregation at Work, Open University Press, Philadelphia, 1988.

Walby, S, 'Theorizing Patriarchy', Sociology, Volume 23, No. 2, 1989.

William, Lane, Edward 1890. An Account of the Manners and Customs of the Egyptian. London: Ward, Lock and Co., 1890.

Ziegler, Wedad Zenie-, In Search of Shadows; Conversations with Egyptian Women. London and New Jersey: Zed Books, 1988. 